\title{
UPRAVLJANJE RAZVOJEM REZILIJENTNIH GRADOVA: PRIMER OBRENOVCA
}

\author{
Marija Maruna ${ }^{1}$, Ratka Čolić \\ $\mathrm{UDK}=005.931 .11: 711.426$ \\ Danijela Milovanović Rodić ${ }^{3}$ \\ https://doi.org/10.18485/fb_ubur.2018.1.ch2 \\ ${ }^{1}$ Arhitektonski fakultet, Univerzitet u Beogradu, m.ma@sezampro.rs \\ ${ }^{2}$ Arhitektonski fakultet, Univerzitet u Beogradu, colic.ratka@gmail.com \\ ${ }^{3}$ Arhitektonski fakultet, Univerzitet u Beogradu, danmilrod@gmail.com
}

Sažetak

Koncept rezilijentnog sistema i upravljanje rizicima od katastrofa (URK)

Koncept rezilijentnog sistema označava skup raspoloživih resursa i kapaciteta kao odgovor na poremećaje u vidu izrade/formulisanja i sprovođenja efikasnih strategija prilagođavanja/adaptacije koji omogućavaju sistemu da se izbori sa sadašnjim i budućim događajima. Jačanje rezilijentnosti urbanih sistema pre svega se odnosi na uspostavljanje efikasnog upravljanja rizicima od katastrofa. U opštem smislu URK podrazumeva sprovođenje aktivnosti pre, za vreme i nakon katastrofa radi izbegavanja ili ublažavanja posledica katastrofa. Savremeni koncepti URK-a promovišu promenu prirode donošenja odluka u cilju identifikovanja benefita koncepta samoodrživosti i fokusiranost na razvoj kapaciteta za prilagođavanje klimatskim promenama (UNISDR 2014). Iako suštinska odgovornost za efikasno URK leži na državnoj upravi, koncept rezilijentnosti počiva na kapacitetima zajednice. To podrazumeva integraciju aktivnosti društva i institucija, uz snažnu institucionalnu osnovu, koja se može obezbediti putem: izgradnje kapaciteta, adekvatnog upravljanja, promocije politika i legislative, informisanja i sprovođenja efikasnih mehanizama koordinacije.

Smatra se da lokalni nivo uprave predstavlja prvu liniju odgovornosti i da je stepen zaštite od katastrofa direktno zavisan on njenih kapaciteta. Iako su preduslovi za uspešno URK odgovarajuće politike i institucionalni okvir, izgradnja rezilijentnih zajednica postaje jedan od glavnih zadataka lokalne uprave. Lokalne vlasti imaju institucionalnu i političku odgovornost da zaštite svoje građane i one su prvi nivo upravljanja koji preduzima mere za smanjenje rizika od katastrofa, priprema odgovore na buduće rizike i reaguje na katastrofe (UNISDR, 2012). Kako bi se postiglo jačanje rezilijentnosti gradova, pored lokalne samouprave, moraju biti angažovani svi relevantni stejkholderi: nacionalna uprava, međunarodne i regionalne organizacije, lokalna zajednica, civilno društvo, strukovna udruženja, privatni i korporativni sektor, donatori i akademska zajednica.

Unapređenje upravljanja rizicima od katastrofa na lokalnom nivou predstavlja poseban problem u slučajevima zemalja u razvoju, gde su, osim ekonomskih problema, izraženi ne- 
dovoljna razvijenost stručnih kapaciteta na nivou lokalne uprave, odsustvo strateškog urbanog razvoja, nizak stepen kontrole izgradnje i pružanja usluga te odsustvo učešća građana u odlučivanju. U radu je dat pregled najnovijih pristupa za razradu politika upravljanja rezilijentnim gradovima koje se zasnivaju na stavu da rešavanje problemâ smanjenja rizika od katastrofa treba usmeriti ka jačanju rezilijentnosti sistema u smislu povećanja sposobnosti gradova i zajednica da se blagovremeno i na efikasan način odupru, apsorbuju, prilagode i oporave od posledica prirodnih ili stvorenih katastrofa, uz očuvanje i ponovno uspostavljanje bitnih osnovnih struktura i funkcija.

Ključne reči: upravljanje rizicima od katastrofa, lokalna samouprava, urbana rezilijentnost, integralni urbani projekti

\subsection{Uvod: Koncept rezilijentnog grada}

\subsection{Pojam rezilijentnog sistema}

Iako izvorno potiče iz ekoloških nauka, gde se koristio da opiše biološku sposobnost ekosistema da se prilagodi i napreduje uprkos nepovoljnim uslovima u životnoj sredini (Holling, 1973), termin rezilijentnost danas u mnogim disciplinama podrazumeva koncept šoka i kreiranje mehanizama za oporavak (Resilience Alliance, 2012) i proširen je na oblasti koje naglašavaju vezu između društvenih i ekoloških sistema, stvarajući time novi termin - društveno-ekološka rezilijentnost (Berkes et al, 2003; Folke et al, 2005; Walker \& Salt 2006). Društveno-ekološka rezilijentnost se u savremenoj literaturi definiše kao količina poremećaja koju sistem može apsorbovati a i dalje ostati u istom stanju; stepen do kojeg je sistem u stanju da se samoorganizuje; i stepen do kojeg sistem može da se nosi sa promenama (Wilkinson, 2011). Ona podrazumeva kapacitet sistema da apsorbuje poremećaj i reorganizuje se tokom promena, tako da i dalje zadrži suštinski istu funkciju, strukturu i povratne informacije (Hopkins, 2008; Folke et al, 2010).

Rezilijentni sistemi su u stanju da efikasno odgovore i prilagode se iznenadnim šokovima i stresovima, da izađu osnaženi nakon teških perioda i napreduju upovoljnim vremenima. Rezilijentni sistem podrazumeva skup raspoloživih resursa i kapacitet da odgovori na poremećaje, uključujući sposobnost da proizvede i sprovede efikasne strategije adaptacije pomoću kojih će sistem moći da se izbori sa sadašnjim ili budućim događajima. Karakteristike rezilijentnih sistema uključuju: raznovrsnost, efikasnost, autonomiju, snage, međuzavisnost, prilagodljivost i saradnju (Godschalk, 2003). U metodološkom smislu, rezilijentni sistemi treba da obezbede: a) kapacitet za apsorpciju, oporavak i obnovu nakon udara, b) delovanje sistema kao celine, a ne samo njegovih pojedinačnih delova i c) podjednako uključivanje društvenih, ekoloških, tehnoloških, ekonomskih i institucionalnih aspekata u izgradnji rezilijentnosti sistema (Milovanović Rodić et al, 2015; URBACT, 2016). 


\subsection{Pojam rezilijentnog grada}

Učestalost prirodnih nepogoda, migratorna, kretanja, neplanski rast naselja, pandemije i sl., podstakli su formulisanje koncepta rezilijentnih ${ }^{1}$ gradova čije su osnovne premise da se rizicima može upravljati, te da se na taj način mogu redukovati gubici, kako života ljudi, tako i socijalnih, ekonomskih i ekoloških dobara zajednica. Prema terminologiji Kancelarije UN za smanjenje rizika od katastrofa (engl. United Nations Office for Disaster Risk Reduction) rezilijentnost (engl. resilience) predstavlja sposobnost sistema, zajednice ili društva izloženih hazardima da pruži otpor (engl. resist), apsorbuje (engl. absorb), prilagodi se (engl. accomodate) i oporavi (engl. recover) od efekata hazarda tako da su sve ključne strukture i funkcije efikasno očuvane i pravovremeno obnovljene (UNISDR, 2015).

Slično tome, Program Evropske unije za teritorijalnu kooperaciju (engl. European Territorial Cooperation Programme), koji ima za cilj promovisanje održivog integrisanog urbanog razvoja u evropskim gradovima, smatra da su gradovi rezilijentni ukoliko njihovi sistemi, zajednice, pojedinci, organizacije i preduzeća imaju kapacitet da se oporave, održe svoju funkciju i nastave dalji razvoj nakon šoka ili stresa, bez obzira na njihov uticaj, frekvenciju ili veličinu (Milovanović Rodić et al, 2015; URBACT, 2016).

Rokfelerova fondacija 100 rezilijentnih gradova (eng. 100 Resilient Cities - Pioneered by the Rockefeller Foundation, 100RC) usmerena ka pružanju podrške razvoju rezilijentnih gradova u odnosu na fizičke, društvene i ekonomske izazove 21. veka, smatra da rezilijentnost gradova predstavlja kapacitet individua, zajednica, institucija, privatnog sektora i gradskih sistema da prežive, prilagode se, rastu bez obzira na vrstu hroničnog stresa ili akutnog šoka kojoj su izloženi. Pod hroničnim stresovima se podrazumevaju dešavanja koja slabe strukturu grada na dnevnom ili cikličnom nivou, kao što su visoka nezaposlenost, neefikasan saobraćajni sistem, endemsko nasilje, nedostatak hrane i vode itd. Akutni šokovi predstavljaju iznenadne, snažne događaje koji ugrožavaju grad, kao što su zemljotresi, poplave, izbijanja zaraze, teroristički napadi itd. (100 Resilient Cities, 2015).

Rezilijentnost gradova zahteva multidisciplinarni okvir istraživanja problema ponovnog aktiviranja, mogućnosti za oporavak, razvoj kapaciteta za adaptaciju i transformabilnost urbanih sistema. Koncept rezilijentnosti gradove posmatra kao kompleksne adaptivne sisteme, slične ekosistemima koji se konstantno samoorganizuju i na različite načine istovremeno reaguju na uticaje unutrašnjih i spoljnih faktora (Wilkinson, 2011). Pored toga, rezilijentnost je više strateški nego normativni koncept, pošto njegov osnovni zahtev efektivnosti mora biti eksplicitno baziran na ekološkim, društvenim i ekonomskim aspektima, utemeljen u dinamici specifičnog mesta i integrisan u različite nivoe i razmere delovanja (Pickett, 2004).

1 U profesionalnoj zajednici Srbije ne postoji saglasnost oko adekvatnog prevoda termina resilient cities, te se u naučnim i stručnim radovima i debatama može naići na atribute kao što su: otporan, stabilan, elastičan, fleksibilan, adaptabilan. U nedostatku konsenzusa oko adekvatnog prevoda, koristićemo termin rezilijentan grad. 
1.3. Rizik od katastrofa

Razumevanje rezilijentnih gradova zahteva primarno razumevanje nastanka katastrofa. Rizik od katastrofa nastaje usled interakcije opasnosti sa osetljivim fizičkim, društvenim, ekonomskim i ekološkim faktorima. Rizik od katastrofa se odnosi na potencijalne gubitke u smislu ljudskih života, zdravlja, izvora prihoda, imovine i usluga, koje bi mogla pretrpeti određena zajednica ili društvo u određenom budućem vremenskom periodu (UNISDR, 2012).

Prirodne nepogode, kao ključni uzrok katastrofa, nastaju kao iznenadne promene u funkcionisanju prirodnih sistema. Ove promene sagledane iz perspektive ljudskog društva postaju pretnja, pa samim tim i opasnost, dok njihova realizacija prerasta u nov fenomen - katastrofalni događaj (Smith \& Petley, 2009). Koncentracija populacije u urbanim područjima, formiranje neformalnih naselja, kao i intenzivan pritisak na javnu infrastrukturu dodatno izlaže savremeni grad riziku i povećava nivo njegove ranjivosti (Bruch \& Goldman, 2012). U datom kontekstu ranjivost, kao karakteristika urbanog sistema, opisuje stepen do kojeg je on rezilijentan, tj. osetljiv na uticaje katastrofa (Smith \& Petley, 2009). Verovatnoća da se neka opasnost, kao što su prirodne nepogode, jave i generišu gubitak, definišemo kao rizik, tj. stvarnu izloženost određene vrednosti ljudskog društva realnoj opasnosti.

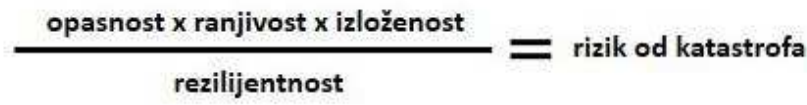

Slika 1. Rizik od katastrofa predstavlja odnos između opasnosti, ranjivosti i izloženosti, sa jedne strane, i rezilijentnosti pojedinca, zajednice ili naselja, sa druge. Izvor: UNISDR, 2012: 7

Zemlje u razvoju posebno su ranjive na delovanje prirodnih hazarda (Bell \& Glade, 2004). Na ranjivost utiču loš administrativni kapacitet upravljanja, nekontrolisana urbanizacija i naseljavanje u zonama izloženim delovanju prirodnih hazarda, odsustvo strateškog planiranja, loša finansijska situacija, neodržavanje ili nepostojanje infrastrukture, ali i neodgovorno ponašanje prema životnoj sredini (FEMA, 2014). Pojam ranjivosti odnosi se na karakteristike i okolnosti neke zajednice, sistema ili njene vrednosti, koje je čine osetljivom na razarajuće posledice opasnosti (UNISDR, 2012).

\subsection{Upravljanje rizicima od katastrofa}

Smanjenje rizika od katastrofa direktno je uslovljeno odgovarajućim upravljanjem rizicima. Upravljanje rizicima kao stručna disciplina obuhvata pripremu za katastrofe pre nego što se one dogode, odgovor na katastrofe i podršku društvu za oporavak nakon katastrofe. Preduzimanje akcija direktno je uslovljeno percepcijom rizika kojima je urbani sistem izložen. Izloženost riziku može da se meri u odnosu na 
verovatnoću, učestalost i jačinu opasnosti, te stoga važan aspekt upravljanja rizicima predstavlja procena rizika. Procena rizika predstavlja preduslov za donošenje odluka, izdvajanje prioritetnih projekata i planiranje mera za smanjenje rizika i prepoznavanje oblasti sa visokim, srednjim i niskim stepenom rizika u aktivnostima upravljanja rizicima (UNISDR, 2012; Maruna, Radosavljević \& Šanta, 2015).

U opštem smislu upravljanje rizicima podrazumeva sprovođenje aktivnosti pre, za vreme i nakon katastrofa. Upravljanje rizicima je proces u kojem svi pojedinci, grupe i zajednice upravljaju rizicima radi izbegavanja ili ublažavanja posledica katastrofa. Efikasno upravljanje rizicima se zasniva na integraciji aktivnosti društva i institucija. Preduslov za efikasno upravljanje rizicima čini kapacitet društva za samoorganizaciju, adaptaciju i učenje, pri čemu kapacitet za samoorganizaciju označava mogućnost sistema da održava i ponovo stvori svoj identitet, a sposobnost za učenje i adaptaciju podrazumeva da sistem može postati bolji u ostvarivanju specifičnog skupa ciljeva u upravljanju tokom vremena i u borbi sa novim ciljevima u slučaju promena u okruženju. (Adger, 2005; Brooks, 2005; Folke et al, 2005; Maruna et al, 2015).

Upravljanje rizicima od katastrofa u gradovima donosi mnoge prednosti, a kada se uspešno primenjuju kao deo održive urbanizacije, rezilijentni gradovi pomažu u smanjenju siromaštva, osiguravaju rast i zapošljavanje i ostvaruju veću socijalnu jednakost, nove poslovne prilike, uravnoteženiji ekosistem (UNISDR, 2012).

Upravljanje razvojem rezilijentnih gradova posebno karakterišu:

- integrativnost - povezivanje ciljeva i aktivnosti između različitih sektora radi razvijanja zajedničkog razumevanja i shodno tome izradi strateškog programa;

- sistemski pristup - traganje za rešenjima koja slabosti i rizike posmatra kao prilike;

- transformativnost - razvoj novih planskih pristupa koji pre svega promovišu redundantnost i fleksibilnost;

- kontekstualnost - uključivanje društvenih, ekoloških, ekonomskih i institucionalnih podsistema prilikom razvoja politika;

- usmerenost ka zajednici - dublje razumevanje mogućnosti i prepreka za prevazilaženje socijalne ranjivosti i društvenih problema (URBACT, 2016).

Odgovornost za efikasno upravljanje rizicima od katastrofa leži na državnoj upravi. Međutim, efikasno upravljanje, pored delovanja državne uprave, podrazumeva interakciju različitih aktera, što uključuje privatni sektor i neprofitne organizacije. Posmatrano iz tog ugla, upravljanje sadrži strukture i procese pomoću kojih društva dele vlast, oblikuju individualne i kolektivne akcije (Young, 1992). Savremeni koncepti upravljanja rizicima od katastrofa u smislu unapređenja rezilijentnosti podrazumevaju promenu prirode donošenja odluka u cilju prepoznavanja benefita o samoodrživosti i novih oblika upravljanja koji su više fokusirani na socijalnu jednakost, učenje i kapacitet za prilagođavanje (UNISDR, 2012).

Takav proces upravljanja rizicima može biti formalno institucionalizovan, uređen kroz suptilna pravila interakcije i oblikovan kontekst u kojem akteri donose 
odluke i određuju pristup resursima. U tom smislu, upravljanje uključuje zakone, propise, diskurzivne debate, pregovore, medijaciju, rešavanje konflikata, izbore, javne konsultacije, proteste i druge procese donošenja odluka (Lebel et al, 2006). Sa druge strane, učestalost i porast šteta od katastrofa dovode do sve veće zainteresovanosti javnosti da bude informisana o riziku od katastrofa kao i o merama za efikasno upravljanje rizikom.

Iako suštinska odgovornost za efikasno upravljanje rizicima leži na državnoj upravi, koncept rezilijentnosti počiva na kapacitetima zajednice. To podrazumeva integraciju aktivnosti društva i institucija, uz snažnu institucionalnu osnovu, koja se može obezbediti putem: izgradnje kapaciteta, adekvatnog upravljanja, promocije politika i legislative, informisanja i sprovođenja efikasnih mehanizama koordinacije (Maruna et al, 2015; Čolić et al, 2015; Milovanović Rodić et al, 2015).

\subsection{Strateški dokumenti na globalnom nivou}

Kao vrednosni, a potom i kao metodološki okvir, upravljanje razvojem rezilijentnih gradova postaje predmet rada relevantnih istraživača i institucija međunarodne zajednice, pre svega Ujedinjenih nacija (UNISDR), još devedesetih godina prošlog veka. Koordinacija napora u tretiranju rizika od katastrofa započeta je već 1990 . godine kada je proglašena Međunarodna decenija za redukciju prirodnih katastrofa (engl. International Decade for Natural Disaster Reduction) sa osnovnim ciljem organizovanog delovanja ka smanjenju broja izgubljenih života, uništene imovine i socijalnih i ekonomskih prekida izazvanih prirodnim katastrofama. Prva Svetska konferencija o redukciji rizika od katastrofa (engl. The World Conference on Disaster Reduction) održana je u Jokohami 1994. godine u okviru koje je usvojena i odgovarajuća tzv. Jokohamska strategija (engl. Yokohama strategy) sa pet osnovnih oblasti za formulisanje plana delovanja, koje apostrofiraju poremećaje razvoja ljudskih zajednica usled prirodnih katastrofa.

Devet godina kasnije, 1999, usvojena je Međunarodna strategija za smanjenje rizika (engl. International Strategy for Disaster Risk Reduction - ISDRR), čija se ključna preporuka tiče redefinisanja tradicionalnog razumevanja i tretmana rizika u smislu razvoja odgovora na katastrofe kroz aktivniji odnos prema redukciji rizika i razvoja „kulture prevencije“.

Godine 2005. održana je druga Svetska konferencija o smanjenju rizika od katastrofa u Hjogu, na kojoj je formulisan Hjogoanski okvir za akciju (UNISDR, 2005) (engl. Hyogo Framework for Action). Hjogoanski okvir predstavlja razradu strategije i definiše prioritete, akcije $\mathrm{i}$ indikatore za izgradnju rezilijentnih zajednica i nacija. Vremenski horizont okvira bio je 2015. godina. Poseban značaj Hjogoanskog okvira sastoji se u organizovanju skupa aktivnosti koje su usmerile pažnju na značaj lokalne zajednice u redukciji rizika od katastrofa i na taj način apostrofirale važnost osnaživanje njene uloge. Radi realizacije prioriteta Hjogoanskog okvira 2010. godine je pokrenuta globalna kampanja „Povećanje rezilijentnosti gradova - moj grad se priprema“ (UNISDR, 2012) (engl. Making Cities Resilient My city is getting ready!), koja je bila namenjena lokalnim samoupravama. Prema 
izveštajima UNISDR-a, kampanja je uključila 2.517 gradova u različite aktivnosti koje doprinose redukciji rizika od katastrofa. Jedan od rezultata pokrenute kampanje predstavlja i priručnik „Kako učiniti gradove rezilijentnijim: priručnik za lidere lokalnih samouprava“" (UNISDR, 2012) (engl. How to Make Cities More Resilient: A Handbook For Local Government Leaders), u kojem je pobrojano 10 tema od značaja za upravljanje rizikom i formiranje rezilijentnog grada na lokalnom nivou, među kojima su i urbanističko planiranje i građevinska regulativa.

Prema Sendaijevskom okviru, najnovijem globalnom instrumentu za smanjenje rizika od katastrofa, koji je usvojila Kancelarija UN za smanjenje rizika od katastrofa (UNISDR, 2015) formiran je opšti okvir i razvijeni odgovarajući alati kao podrška lokalnim upravama za upravljanje razvojem rezilijentnih gradova. Njihov osnovni cilj je usmeravanje upravljanja višestrukim rizicima od katastrofa na svim nivoima vlasti i u okviru svih sektora (Tabela 1).

Rezilijentnost gradova je važna tema i najnovijeg globalnog dokumenta Agende 2030 UN pod nazivom „Transformišući naš svet: Agenda za održivi razvoj do 2030. godine“" (engl. Transforming Our World: the 2030 Agenda for sustainable development). Kao njen deo, usvojen je skup Ciljeva održivog razvoja (UN, 2015a), usmerenih ka rešavanju problema siromaštva, zaštite životne sredine i obezbeđenja prosperiteta celokupnom čovečanstvu u narednih petnaest godina. U okviru sedamnaest načelnih ciljeva, rezilijentnost gradova zauzima važnu komponentu. Naime, uprkos borbi za ostvarenje konkurentne pozicije u okviru globalnog tržišta, uz obezbeđenje blagostanja svojim građanima, gradovi generišu ekstremno siromaštvo, dovode do degradacije životne sredine i pogoduju ostvarenju velikog bogatstva interesnim grupama.

Izdvajanjem samostalnog cilja o gradovima (Cilj 11), poznatog i kao „urbani cilj održivog razvoja“ - Učiniti gradove i ljudska naselja inkluzivnim, bezbednim, rezilijentnim i održivim - međunarodna zajednica je identifikovala urbanizaciju i rast gradova kao transformišuću silu razvoja, odnosno urbani razvoj kao fundamentalni preduslov održivog razvoja (UN, 2015b).

Tabela 1. Pregled strateških prioriteta za upravljanje razvojem rezilijentnih gradova na globalnom nivou

\begin{tabular}{|l|l|l|l}
\hline \multicolumn{4}{c}{ PREGLED STRATESKKIH PRIORITETA ZA UPRAVLJANJE RAZVOJEM } \\
REZILIJENTNIH GRADOVA NA GLOBALNOM NIVOU
\end{tabular}


globalnom nivou veoma je važno za prevenciju, ublažavanje, spremnost, odgovor, oporavak i rehabilitaciju

(2) Identifikovati, proceniti i pratiti rizike od katastrofa i unaprediti rano upozoravanje

(1) Upravljanje: organizacioni, pravni i politički okvir

(3) Upravljanje znanjem i obrazovanjem (2) Obavezivanje javnih vlasti na smanjenje rizika po ljude, njihov život, društvenu i ekonomsku infrastrukturu te životnu sredinu

(2) Identifikacija rizika, procena, monitoring i rano obaveštavanje

(4) Redukovanje osnovnih faktora rizika

(5) Spremnost na efektivnu pripravnost i obnovu

ranjivost, kapacitet, izloženosti ljudi i imovine, karakteristike opasnosti i okoline

(3) Uključivanje učešća građana na svim nivoima implementacije kako bi se stvorile zajednice koje su otporne na katastrofe, kroz razvoj partnerskih mreža

(3) Koristiti znanje, inovacije $i$ obrazovanje kako bi se izgradila kultura sigurnosti i rezilijentnosti na svim nivoima

(4) Smanjenje ekonomskih i društvenih gubitaka od katastrofa mereno $\mathrm{u}$ odnosu na bruto domaći proizvod (4) Smanjiti osnovne faktore rizika
(3) Ulaganje u smanjenje rizika od katastrofa radi rezilijentnosti Javna i privatna ulaganja u sprečavanje i smanjenje rizika od katastrofa kroz strukturne i nestrukturne mere od suštinskog su značaja za poboljšanje ekonomske, društvene, zdravstvene i kulturne rezilijentnosti osoba, zajednica, zemalja i njihove imovine, kao i životne sredine

(4) Poboljšanje spremnosti na katastrofe za efikasan odgovor i za bolju izgradnju tokom oporavka, rehabilitacije i rekonstrukcije porast rizika od katastrofa znači da postoji potreba za jačanjem spremnosti za odgovore, preduzimanje akcija u predviđanju događaja i osiguranju kapaciteta za efikasan odgovor i oporavak na svim nivoima

(5) Jačati spremnost na katastrofe kao efektivni odgovor na svim nivoima 


\subsection{Institucionalni okvir i njegov značaj za povećanje rezilijentnosti gradova}

Efikasno smanjenje rizika od katastrofa zahteva snažnu institucionalnu osnovu, koja se može osigurati putem: izgradnje kapaciteta, dobrog upravljanja, promocije odgovarajućih politika i legislative, omogućavanja informisanja i efikasnih mehanizama koordinacije. Ključne aktivnosti koje treba sprovesti u cilju stvaranja jake institucionalne osnove pre svega su izgradnja nacionalnog i zakonodavnog okvira, obezbeđenje resursâ i podsticanje učešća zajednice u smanjenju rizika od katastrofa. Naročito je važna uloga institucionalnog okvira u podsticanju učešća svih stejkholdera u smanjenju rizika od katastrofa, kroz usvajanje konkretnih politika, promovisanje umrežavanja, strateško upravljanje, dodeljivanje uloga i odgovornosti, kao i delegiranje i obezbeđivanje neophodnih resursa.

Kako bi se postiglo povećanje rezilijentnosti gradova, potrebno je da se poveća sposobnost gradskih institucija, kao i da se stvori mreža upravljanja u cilju ostvarivanja adaptivnog planiranja, integracije novih ideja i koordinacije između različitih aktera (Evans, 2011; Folke et al, 2005; Leichenko, 2011). To se može postići, naročito, proširenjem dostupnosti informacija u planiranju i povećanjem fleksibilnosti sistema za kreiranje i testiranje novih ideja i politika. Povećanje rezilijentnosti odnosi se i na sprovođenje aktivnosti za smanjenje rizika putem analize uzročnih faktora, smanjenje izloženosti opasnostima, umanjenje ranjivosti ljudi i okoline, upravljanje zemljištem i poboljšanje spremnosti na katastrofe. Tome pogotovo doprinosi sveobuhvatna mreža ustanova koje pomažu u smanjenju rizika od katastrofa.

\subsection{Lokalni nivo upravljanja}

Smatra se da lokalni nivo uprave predstavlja prvu liniju odgovornosti i da je stepen zaštite od katastrofa direktno zavisan on njenih kapaciteta. Iako su preduslovi za uspešno upravljanje rizicima odgovarajuće politike i institucionalni okvir, izgradnja rezilijentnih zajednica postaje jedan od glavnih zadataka lokalne uprave.

Unapređenje upravljanja rizicima od katastrofa na lokalnom nivou predstavlja poseban problem u slučajevima zemalja u razvoju, gde je, pored ekonomskih problema, izražena nedovoljna razvijenost stručnih kapaciteta na nivou lokalne uprave, odsustvo strateškog urbanog razvoja, nizak stepen kontrole izgradnje i pružanja usluga i odsustvo učešća građana u odlučivanju.

Lokalni nivo uprave je od ključnog značaja za rešavanje klimatski generisanih ili klimatski odgovornih izazova. Lokalne vlasti imaju institucionalnu i političku odgovornost da zaštite svoje građane i one su prvi nivo upravljanja koji preduzima mere za smanjenje rizika od katastrofa, priprema odgovore na buduće rizike i reaguje na prirodne katastrofe (UNISDR, 2012). Kako bi se postiglo jačanje rezilijentnosti gradova, osim lokalne samouprave, moraju biti angažovani svi relevantni stejkholderi: nacionalna uprava, međunarodne i regionalne organizacije, lokalna zajednica, civilno društvo, strukovna udruženja, privatni i korporativni sek- 
tor, donatori i akademska zajednica. Institucionalni i administrativni okvir lokalne samouprave direktno utiče na organizaciju i koordinaciju uloga i odgovornost svakog aktera.

U nadležnosti lokalne samouprave je pružanje usluga u domenu zdravstva, obrazovanja, saobraćaja, vodosnabdevanja, izdavanja građevinskih dozvola, upravljanja javnim radovima, kontrole urbanog razvoja, što sve pruža mogućnost za ostvarivanje sigurnijeg razvoja i smanjenje osetljivosti zajednice na katastrofe. Da bi izvršile svoju obavezu zaštite života, imovine, privrede i okoline, potrebni su im znanje, instrumenti, kapaciteti i resursi.

Neka od važnih pitanja od značaja za povećanje rezilijentnosti gradova koja se tiču lokalne samouprave jesu:

- kapacitet lokalne samouprave (znanje, iskustvo, ovlašćenja) za smanjenje rizika od katastrofa,

- stepen saradnje između građana, privatnog sektora i lokalnih vlasti u aktivnostima smanjenja rizika od katastrofa,

- $\quad$ stepen uključivanja ranjivih grupa građana (žena, starih, bolesnih, dece itd.) u aktivnostima donošenja odluka, formiranja politika upravljanja i procesu njihovog sprovođenja u cilju smanjenja rizika od katastrofa,

- stepen učešća lokalne samouprave u planiranju prevencije i smanjenju rizika od katastrofa na nacionalnom nivou (UNISDR, 2012).

\subsection{Najnoviji pristupi za formiranje politika upravljanja rezilijentnim gradovima}

Poslednjih godina sve su učestaliji napori međunarodnih organizacija ka operacionalizaciji principâ i razvoju instrumenata upravljanja rezilijentnim gradovima. Prihvaćen je stav da se rezilijentnost može postići uvođenjem preciznih i inventivnih mera unapređenja urbanog sistema na operativnom i strukturnom nivou. Usaglašeno je mišljenje da rešavanje problema smanjenja rizika od katastrofa treba usmeriti ka jačanju rezilijentnosti sistema u smislu povećanja sposobnosti gradova i zajednica da se blagovremeno i na efikasan način odupru, apsorbuju, prilagode i oporave od posledica prirodnih ili stvorenih katastrofa, uz očuvanje i ponovno uspostavljanje bitnih osnovnih struktura i funkcija (UNISDR, 2011).

$\mathrm{U}$ narednim poglavljima biće predstavljena tri pristupa za formiranje politika upravljanja rezilijentnim gradovima: (1) Operativni okvir Sendaijevskog okvira na lokalnom nivou (engl. An operational framework of Sendai Framework at local level) (UNISDR, 2015), (2) OECD osnove za razvoj politika (engl. Policy highlights of the OECD Report) (OECD, 2016), i (3) Okvir za rezilijentne gradove - projekta 100 rezilijentnih gradova (engl. The City Resilience Framework) (100 resilient cities, 2015). 


\subsection{Operativni okvir Sendaijevskog okvira na lokalnom nivou}

U cilju implementacije Sendaijevskog okvira za smanjenje rizika od katastrofa na lokalnom nivou, razvijeno je deset osnovnih prioritetnih tema za razvoj rezilijentnih gradova (UNISDR, 2015). One predstavljaju bitne i nezavisne korake koje treba preduzeti da bi se izgradila i održala rezilijentnost. Svaka tema obrađuje jednu stratešku oblast intervencije i identifikuje odgovarajuće ključne aktivnosti. Svaka akcija treba da bude deo celokupnog procesa planiranja smanjenja rizika od katastrofa i da utiče na planiranje urbanog razvoja (Tabela 2).

Tabela 2. Deset ključnih tema operativnog okvira Sendaijevskog okvira za smanjenje rizika od katastrofa (prema: UNISDR, 2015)

\begin{tabular}{|c|c|c|}
\hline (1) & $\begin{array}{l}\text { Organizovati se za otpornost na kata- } \\
\text { strofu }\end{array}$ & $\begin{array}{l}\text { - Uspostaviti i ojačati institucionalni kapa- } \\
\text { citet na lokalnom nivou } \\
\text { - } \quad \text { Izgraditi saveze i mreže } \\
\text { - } \quad \text { Formirati zakonodavni okvir i mehani- } \\
\text { zme delovanja za rezilijentnost }\end{array}$ \\
\hline $\begin{array}{l}\text { (2) } \\
\text { - } \\
\text { - } \\
\text { - } \\
\text { (3) }\end{array}$ & $\begin{array}{l}\text { Jačati finansijski kapacitet za rezilijent- } \\
\text { nost } \\
\text { Identifikovati najverovatnije i najteže } \\
\text { scenarije (najgori slučaj) } \\
\text { Prepoznati prilike gde izgradnja rezili- } \\
\text { jentnosti doprinosi zdravoj ekonomskoj } \\
\text { strategiji } \\
\text { Obezbediti budžet za rezilijentnost } \\
\text { Širiti informacije o riziku u cilju dono- } \\
\text { šenja odluka o razvoju } \\
\text { Iskoristiti znanje iz scenarija rizika za } \\
\text { razvojne odluke } \\
\text { identifikovati, razumeti i koristiti scena- } \\
\text { rije za procenu trenutnog i budućeg rizika }\end{array}$ & \\
\hline (4) & $\begin{array}{l}\text { Nastaviti rezilijentan urbani razvoj i di- } \\
\text { zajn }\end{array}$ & 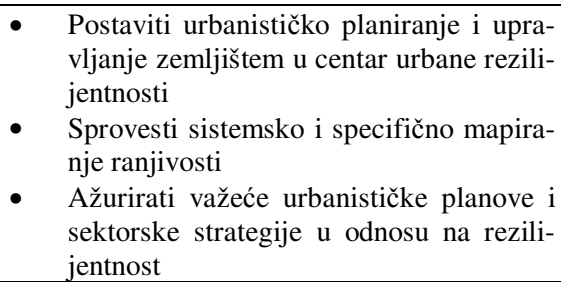 \\
\hline (5) & $\begin{array}{l}\text { Zaštititi prirodne amortizacione zone za } \\
\text { poboljšanje zaštitnih funkcija ekosistema } \\
\text { Podići svest o uticaju promena u životnoj } \\
\text { sredini i degradaciji ekosistema na rizik } \\
\text { od katastrofa } \\
\text { Promovisati bolje upravljanje kritičnim } \\
\text { ekosistemima radi jačanja rezilijentnosti } \\
\text { na katastrofe } \\
\text { Ojačati dosadašnje upravljanje ekosiste- } \\
\text { mima na osnovu scenarija procene rizika }\end{array}$ & $\begin{array}{l}\text { (6) Jačati institucionalne kapacitete za rezili- } \\
\text { jentnost }\end{array}$ \\
\hline
\end{tabular}


(7) Razumeti i jačati društvene kapacitete za rezilijentnost

- Identifikovati specifičnu prirodu svake ranjivosti i povezati sa odgovarajućom institucijom

- Izgraditi lokalne kapacitete i učvrstiti učešće u upravljanju katastrofama i poboljšanju rezilijentnosti

- Obezbediti konzistentnost podataka i informacija o rizicima među učesnicima

(8) Obezbediti efektivni odgovor na katastrofu

- Proceniti kapacitete i adekvatnost kritične infrastrukture

- Ojačati/nadograditi ugroženu infrastrukturu

- Uspostaviti partnerstva između uprave za životnu sredinu i privatnog sektora

- Identifikovati relevantnost prioritetnih usluga i aktivnosti tokom i nakon katastrofa

(9) Povećati rezilijentnost infrastrukture

(10) Ubrzati oporavak i ponovnu izgradnju
- Uspostaviti dobro opremljene jedinice za reagovanje na lokalnom nivou

- Razviti informacije o smanjenju rizika i rezilijentnosti

- Integrisati smanjenje rizika od katastrofa i rezilijentnosti $u$ formalno obrazovanje $i$ druge programe

- Unaprediti javno obrazovanje i svest putem širenja informacija kroz medije

- $\quad$ Prikupiti i ažurirati dostupne podatke za razvoj spremnosti na katastrofe

- Kreirati i poboljšati planove za reagovanje

- Jačati sisteme ranog upozoravanja

- Unaprediti gradske službe za hitno reagovanje
- Oporavak mora biti saglēdan sa različitih aspekata

- Uključiti ugroženo stanovništvo u definisanje potreba i planove oporavka

- Oporavak je prilika da se bolje gradi i poboljša razvoj

- Tražiti resurse, ojačati saveze i obezbediti održivost

\subsection{Osnove OECD-a za razvoj politika}

Juna 2016. godine Organizacija za ekonomsku saradnju i razvoj, OECD (engl. Organisation for Economic Co-operation and Development), usvojila je preliminarnu verziju izveštaja o rezilijentnim gradovima (OECD, 2016) sa ciljem istraživanja mogućnosti za uvećanje rezilijentnosti gradova. I u ovom dokumentu se smatra da su rezilijentni gradovi oni koji imaju sposobnost da apsorbuju, oporave se i pripreme za buduće šokove (ekonomske, ekološke, društvene i institucionalne). Pored toga, smatra se da rezilijentni gradovi promovišu održivi razvoj, blagostanje i inkluzivni rast. U izveštaju su izdvojeni osnovni pristupi razvoju politika rezilijentnosti koji naglašavaju važnost saradnje sa drugim učesnicima, kao što su nacionalni nivo uprave, susedne opštine, nevladine organizacije, građani i privatni sektor (Tabela 3). 
Tabela 3. Osnovne sugestije za razvoj politika rezilijentnosti iz izveštaja OECD-a (prema: OECD, 2016)

(1) Adaptivne - u stanju su da deluju na osnovu iskustva iz prošlosti

- Podsticanje pojedinaca i kompanija za razvoj inovativnosti

- Primena politika kompaktnog grada za postizanje ciljeva održivog razvoja u gradovima sa rastom populacije

(2) Snažne - imaju dobro uobličen sistem za prihvatanje šokova

- Podrška novim konkurentnim industrijama za ohrabrivanje industrijske diversifikacije

- Razvoj strategija investiranja u pouzdanu infrastrukturu

(3) Redundantne - imaju sačuvan kapacitet za neočekivane potrebe

- Investiranje u infrastrukturu radi stvaranja dodatnih kapaciteta za suočavanje sa kritičnim situacijama

- Strateško planiranje namene površina radi višestrukog korišćenja zemljišta

(4) Fleksibilne - reaguju na izmenjene okolnosti u planovima

- Dugoročna vizija pruža smernice u promenljivim okolnostima

- Preduzetništvo i inovacije nude gradovima mogućnost za razvoj novih ekonomija u promenljivim uslovima

(5) Iznenađujuće - imaju načine da nađu re-

- Specijalizovane administrativne jedinice surse za zadovoljenje kritičnih potreba za rezilijentnost jačaju resurse javnog sektora

- Gradovi moraju da istraže fiskalne reforme

(6) Inkluzivne - udružuju različite perspektive

- Uključivanje stejkholdera može da unapredi kvalitet politika i da ojača lokalne zajednice

- Obezbediti pristup mogućnostima za sve građane

(7) integralne - rade zajedno izvan granica

- Upravljanje na više nivoa vlasti promoviše bolju koordinaciju politika

- Univerziteti mogu postati centri saveza

- Savezi sa drugim gradovima omogućavaju delovanje na nivou metropolitenskog područja 


\subsection{Okvir za rezilijentne gradove - projekat 100 rezilijentnih gradova}

Okvir za rezilijentne gradove je razvila organizacija ARUP, uz podršku Rokfelerove fondacije (100 resilient cities, 2015). Kreiran je sa ciljem razumevanja kompleksnosti gradova i pokretačkih sila koje utiču na njegovu rezilijentnost. Istovremeno, predloženi okvir je namenjen stvaranju svojevrsnog zajedničkog jezika za razumevanje i deljenje znanja i iskustava među gradovima. Postavljanje istraživačkog fokusa na pokretačke sile u gradovima omogućava procenu kapaciteta rezilijentnosti, identifikaciju kritičnih slabosti i identifikaciju aktivnosti i programa za poboljšanje rezilijentnosti gradova.

Okvir za rezilijentne gradove utemeljen je u četiri osnovne dimenzije urbane rezilijentnosti: (1) zdravlje i blagostanje; (2) ekonomija i društvo; (3) infrastruktura i životna sredina i (4) liderstvo i strategije. Svaka dimenzija sadrži tri ,pokretačke sile" kakve reflektuju akcije koje gradovi treba da preduzmu da bi unapredili sopstvenu rezilijentnost (Tabela 4).

Tabela 4. Okvir za rezilijentne gradove (prema: 100 resilient cities, 2015)

\begin{tabular}{|c|c|}
\hline (1) Zdravlje i blagostanje & 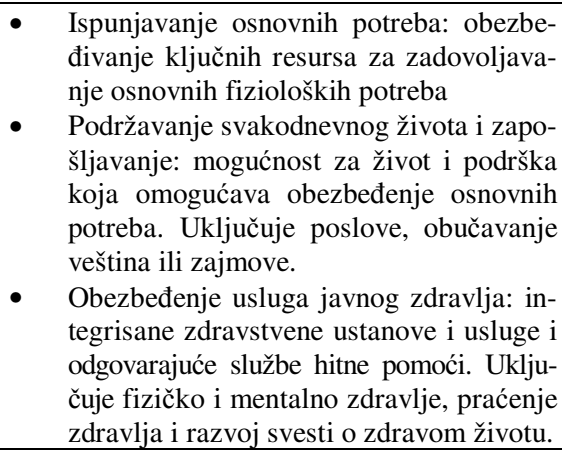 \\
\hline (2) Ekonomija i društvo & $\begin{array}{l}\text { - Promovisanje kohezivnih i angažovanih } \\
\text { zajednica: angažovanje zajednica, dru- } \\
\text { štvene mreže i integracija. One ojačavaju } \\
\text { kolektivne sposobnosti za poboljšavanje } \\
\text { zajednice i zahtevaju procese koji podsti- } \\
\text { ču građansko angažovanje u planiranju i } \\
\text { odlučivanju. } \\
\text { Obezbeđenje društvene stabilnosti, bez- } \\
\text { bednosti i pravde: unapređenje zakona, } \\
\text { prevencija kriminala, sudstvo i upravlja- } \\
\text { nje vanrednim situacijama. } \\
\text { Podržavanje ekonomskog prosperiteta: } \\
\text { podrška ekonomskom razvoju u širem } \\
\text { smislu. Važni ekonomski faktori uklju- } \\
\text { čuju: planiranje nepredviđenih okolnosti, } \\
\text { dobro upravljanje gradskim finansijama, } \\
\text { sposobnost privlačenja poslovnih ulaga- } \\
\text { nja, razvoj različitih ekonomskih profila i } \\
\text { širenje mreža. }\end{array}$ \\
\hline
\end{tabular}




\begin{tabular}{|c|c|}
\hline (3) Infrastruktura i životna sredina & $\begin{array}{l}\text { - Unapređenje i zaštita prirodnih i stvore- } \\
\text { nih dobara: upravljanje životnom sredi- } \\
\text { nom, odgovarajuća infrastruktura, efika- } \\
\text { sno planiranje korišćenja zemljišta i } \\
\text { sprovođenje propisâ. } \\
\text { Obezbeđenje kontinuiteta usluga za kri- } \\
\text { tične situacije: raznolikost usluga, redun- } \\
\text { dantnost, aktivno upravljanje i održava- } \\
\text { nje ekosistema i infrastrukture i planira- } \\
\text { nje nepredviđenih situacija. } \\
\text { Obezbeđenje pouzdanih komunikacija i } \\
\text { mobilnosti: raznolika i dostupna multi- } \\
\text { modalna mreža saobraćaja (putevi, žele- } \\
\text { znica, putne oznake, signalizacija itd.), } \\
\text { opcije javnog saobraćaja i logistika (luke, } \\
\text { aerodromi, teretne linije itd.) }\end{array}$ \\
\hline (4) Liderstvo i strategije & 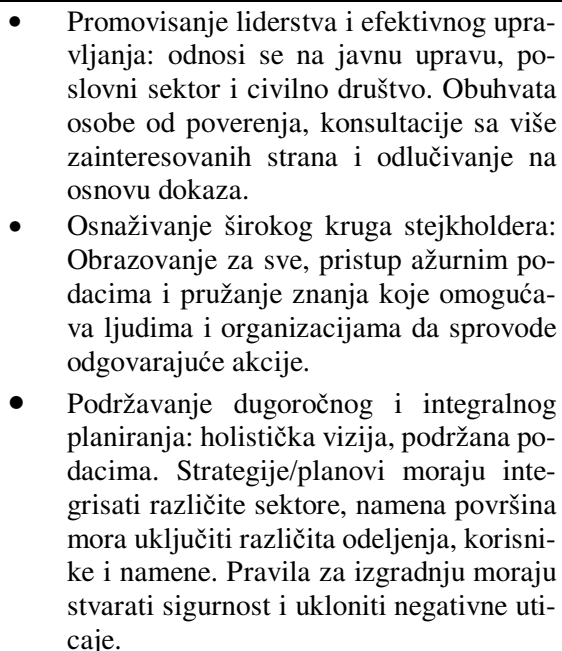 \\
\hline
\end{tabular}

Zajednički imenitelj navedenim pristupima za formiranje politika upravljanja rezilijentnim gradovima čini sedam kvaliteta koje rezilijentni gradovi treba da sadrže: a) sposobnost učenja iz prošlih događaja, b) obezbeđenost resursima, c) otpornost na šokove, d) sposobnost za pronalaženje alternativnih strategija, e) fleksibilnost u delovanju, f) inkluzivnost i otvorenost za različite učesnike, g) integraciju ljudi, resursa i institucija.

\subsection{Zaključak}

Učestalost prirodnih nepogoda, kao i nepogoda nastalih društveno-ekonomskim problemima, poslednjih decenija značajno utiču na porast broja nastradalih i stvaranje ekonomskih gubitaka. Navedeni kompleksni razvojni problemi podstakli su međunarodnu javnost ka formulisanju koncepta rezilijentnih gradova, čije su 
osnovne premise da se rizicima može upravljati, te da se na taj način mogu redukovati gubici, kako života ljudi, tako i društvenih, ekonomskih i ekoloških dobara zajednica.

Uloga lokalnih vlasti je opažena kao ključna u suočavanju sa smanjenjem rizika od katastrofa i razvoju rezilijentnih zajednica. Smatra se da zajednicama i lokalnim vlastima treba preneti odgovornost za upravljanje smanjenjem rizika od katastrofa putem obezbeđenja pristupa neophodnim informacijama, resursima i davanjem ovlašćenja za sprovođenje akcija.

Slaba uprava, neformalna naselja na nebezbednom zemljištu, ugroženost ekosistema i ruralne sredine glavni su pokretači rizika koje treba adresirati za izgradnju rezilijentnijih gradova. U cilju smanjenja rizika od katastrofa potrebno je preduzeti akcije u skladu sa odgovarajućim upravljanjem rizicima. Prioritetna akcija u upravljanju rizicima jeste procena rizika koji postoje na određenom području i planiranje mera za pravovremeno reagovanje u situacijama pre, tokom i nakon prirodnih katastrofa.

\section{Literatura}

1. 100 resilient cities (2015). City Resilience Framework. The Rockefeller Foundation \& ARUP (Korišćeno 19. jula 2017), http://lghttp.60358.nexcesscdn.net/8046264/images/page/-/100rc/Blue\%20City\%20Resilience\%20Framework\%20Full\%20Context $\% 20$ v1_5.pdf

2. Adger, N. W., and K. Vincent (2005). Uncertainty in adaptive capacity. Comptes Rendus Geoscience 337: 399-410.

3. Bell, R., \& Glade, T. (2004). Multi-Hazard Analysis in Natural Risk Assessment. Bonn: Department of Geography, University of Bonn.

4. Berkes, F., J. Colding, et al. (Eds.) (2003). Navigating socialecological systems: Building resilience for complexity and change. Cambridge, UK: Cambridge University Press.

5. Brooks, N., N. W. Adger, and P. M. Kelly (2005). The determinants of vulnerability and adaptive capacity at the national level and the implications for adaptation. Global Environmental Change 15: 151-163.

6. Bruch, C., \& Goldman, L. (2012). Keeping up with megatrends: the implications of climate change and urbanization for environmental emergency preparedness and response. Geneva, Switzerland: Joint UNEP/OCHA Environment Unit.

7. Čolić, R., Bugarski, J., Mačkić, I. (2015). Otpornost na promene u planiranju infrastrukture - primer Obrenovca. Zbornik radova sa 40. naučne konferencije $O M O$ Održavanje mašina $i$ opreme, Mašinski fakultet Univerziteta u Beogradu, Budva, 23-26. jun.

8. Č́lić, R., Maruna, M., Milovanović Rodić, D., Lalović, K. (Ur.) (2015). Integralni urbani projekti za upravljanje rizikom od poplava na primeru Obrenovca: katalog izložbe završnih radova generacije studenata 2013/14. [Integrated Urban Projects for Disaster Risk Management: Case Study of Obrenovac: Final Works' Exhibition Catalogue: Generation of Students 2013/2014]. Beograd: Univerzitet u Beogradu, Arhitektonski fakultet. 
9. Evans, J. P. (2011). Resilience, ecology and adaptation in the experimental city. Transactions of the Institute of British Geographers 36 (2): 223-237.

10. FEMA (2014). Federal Emergency Management agency. Hazard, vulnerability, and risk analysis. Washington (korišćeno 12. marta 2015), http://www.ready.gov/riskassessment

11. Fokdal, J., Zehner, C. (Eds.) (2016). Resilient Cities: Urban Disaster Risk Management in Serbia (Report on the Results of a Case Study Research project (2015)). Berlin: Berlin University of Technology.

12. Folke, C., Carpenter, S.R., Walker, B., Scheffer, M., Chapin, T. and Rockström, J. (2010). Resilience thinking: integrating resilience, adaptability and transformability. Ecology and Society 15 (4), 20.

13. Folke, C., T. Hahn, P. Olsson, and J. Norberg. (2005). Adaptive governance of socialecological systems. Annual Review of Environmental Resources 30: 441-473.

14. Godschalk, D. R. (2003). Urban Hazard Mitigation: Creating Resilient Cities. Natural Hazards Review, 4 (3), 136-143.

15. Holling, C.S. (1973). Resilience and stability of ecological systems. Annual Review of Ecology and Systematics 4: 1-23.

16. Hopkins, R. (2008). The Transition Handbook: From Oil Dependency to Local Resilience. Chelsea: Green Books.

17. Intergovernmental Panel on Climate Change (IPCC) (2007). Climate Change 2007: Synthesis report. IPCC's Fourth Assessment Report (AR4). IPCC, Geneva, Switzerland. http://www.ipcc.ch/

18. Intergovernmental Panel on Climate Change (IPCC) (2012). Managing the Risks of Extreme Events and Disasters to Advance Climate Change Adaptation. A Special Report of Working Groups I and II of the Intergovernmental Panel on Climate Change. U: Field, C.B., V. Barros, T.F. Stocker, D. Qin, D.J. Dokken, K.L. Ebi, M.D. Mastrandrea, K.J. Mach, G.-K. Plattner, S.K. Allen, M. Tignor, and P.M. Midgley (eds.). Cambridge University Press, Cambridge, UK, and New York, NY, USA.

19. Intergovernmental Panel on Climate Change (IPCC) (2012). Managing the Risks of Extreme Events and Disasters to Advance Climate Change Adaptation. A Special Report of Working Groups I and II of the Intergovernmental Panel on Climate Change [Field, C.B., V. Barros, T.F. Stocker, D. Qin, D.J. Dokken, K.L. Ebi, M.D. Mastrandrea, K.J. Mach, G.-K. Plattner, S.K. Allen, M. Tignor, and P.M. Midgley (eds.)]. Cambridge University Press, Cambridge, UK, and New York, NY, USA.

20. Label, L., Anderies, J. M., Campbel, B., Folke, C., \& Hatfield-Dodds, S. (2006). Governance and the Capacity to Manage Resilience in Regional Social-Ecological Systems. Marine Science Faculty Scholarship, Paper 52.

21. Leichenko, R. (2011). Climate change and urban resilience. Current Opinion in Environmental Sustainability 3 (3): 164-168.

22. Maruna, M., Čolić, R. (Ur.) (2015). Inovativni metodološki pristup izradi master rada: doprinos edukaciji profila urbaniste [The innovative methodological approach to the development of master work: A contribution to the education of urban planners profile]. Beograd: Arhitektonski fakultet \& GIZ/AMBERO Beograd.

23. Maruna, M., Colic, R., Fokdal, J., Zehner, C., Milovanovic Rodic, D., Lalovic, K. (2015). Collaborative and practice oriented learning of disaster risk management in post socialist transitition countries. XVI N-AERUS Conference: Who wins and who loses? Exploring and Learning from Transformations and Actors in the Cities of the South. Dortmund, Germany, 19-21 November. 
24. Maruna, M., Radosavljević, J., Kožović, K., Lučić, A. (2015). Institucionalna i administrativna mreža na lokalnom nivou u funkciji upravljanja rizicima od prirodnih katastrofa. Zbornik radova sa 40. naučne konferencije OMO - Održavanje mašina i opreme, Mašinski fakultet Univerziteta u Beogradu, Budva, 23-26. jun.

25. Maruna, M., Radosavljević, J., Šanta, O. (2015). Procena rizika od prirodnih katastrofa i povećanje rezilijentnosti gradova. Zbornik radova sa 40. naučne konferencije $O M O$ Održavanje mašina $i$ opreme, Mašinski fakultet Univerziteta u Beogradu, Budva, 23-26. jun.

26. Milosavljević, B. (2014). Koncepcijske postavke sistema zaštite i spasavanja: predlozi za preispitivanje. Polis, 8, 4-11.

27. Milovanović Rodić, D., Madžarević, M., Đorđević, A. (2015). Prirodne nepogode kao opomena i pouka: urbanističko planiranje za efikasno upravljanje rizicima i podizanje otpornosti naselja. Zbornik radova sa 40 naučne konferencije OMO - Održavanje mašina i opreme, Mašinski fakultet Univerziteta u Beogradu, Budva, 23-26. jun.

28. OECD (2016). Resilient Cities: Policy Highlights of the OECD Report (Preliminary version). (Korišćeno 18. jula 2017), http://www.oecd.org/cfe/regional-policy/resilientcities-policy-highlights-preliminary.pdf

29. Pickett S.T.A., Cadenassso, M.L., Grove, J.M. (2004). Resilient cities: meaning, models, and metaphor for integrating the ecological, socio-economic, and planning realms. Landscape Urban Plan 69, 369-384.

30. Resilience Alliance (2012). Resilience Alliance Website (korišćeno 5. maja 2015). $<$ http://www.resalliance.org/>.

31. Smith, K., \& Petley, D. (2009). Environmental Hazards: Assessing risk and reducing disaster. New York: Taylor \& Francis Group.

32. UN (2015a). Transforming our world: the 2030 Agenda for Sustainable Development (korišćeno 13. jula 2017), http://www.un.org/ga/search/view_doc.asp?symbol=A/ $\mathrm{RES} / 70 / 1 \&$ Lang $=\mathrm{E}$

33. UN (2015b). Sustainable Development Goals (korišćeno 13. jula 2017), http://www. un.org/sustainabledevelopment/sustainable-development-goals/

34. UNDP (2012). United Nations Development Programme. Annual report 2011-2012: The sustainable future we want (korišćeno u martu 2015), <http://www.undp.org/ content/undp/en/home/librarypage/corporate/annual-report-2011-2012--thesustainable-future-we-want.html>.

35. UNISDR (2011). United Nations International Strategy for Disaster Reduction, Geneva (korišćeno 12. aprila 2015), <http://www.unisdr.org/we/inform/publications/19846>

36. UNISDR (2012). How To Make Cities More Resilient: A Handbook For Local Government Leaders. Geneva.

37. UNISDR (2014). United Nations Office for Disaster Risk Reduction. Annual report (korišćeno 20. marta 2015), <http://www.unisdr.org/we/inform/publications/42667>

38. UNISDR (2015). Sendai Framework for Disaster Risk Reduction 2015-2030. (Korišćeno 13. jula 2017), https://www.unisdr.org/files/43291_sendaiframeworkfordrren.pdf

39. UNISDR. (2005). Hyogo Framework for Action 2005-2015: Building the Resilience of Nations and Communities to Disasters. Geneva, Switzerland.

40. URBACT (2016). Urban Resilience: A concept for co-creating cities of the future (korišćeno 14. jula 2017), http://urbact.eu/sites/default/files/media/urban_resilience_ conceptnote_2016_nf.pdf

41. Walker \& Salt (2006). Resilience thinking: Sustaining Ecosystems and People in a Changing World. Island press: Washington, pp. 1-14. 
42. Wilkinson, K.N.D. (2011). EDx Talk: The paradox of urban resilience (korišćeno 15. maja 2015), http://www.stockholmresilience.org/21/research/research-news/9-21-2011the-paradox-of-urban-resilience.html

43. Young, O. R. (1992). The effectiveness of international institutions: hard cases and critical variables. Pages 160-194 in J. N. Rosenau and E.-O. Czempiel (Eds.) Governance without government: order and change in world politics. Cambridge University Press, Cambridge, UK.

\title{
GOVERNANCE OF RESILIENT CITIES: THE CASE OF OBRENOVAC
}

\begin{abstract}
Summary
Climate change and issues of urban governance

Climate change has in recent years become a key topic for policymakers globally, as well as an indispensable framework for governance instruments. The warnings issued by the scientific and professional community about the dangers of climate change (IPCC, 2007; IPCC, 2012) are no longer viewed with suspicion, given the increasingly frequent natural disasters that have been causing great loss of life, destruction and degradation of the environment, massive property damage, and economic losses. The impact of natural disasters on hundreds of millions of people worldwide has spurred policymakers to take urgent steps to address these issues appropriately (UNDP, 2012). The common position is that efforts to respond to climate change ought to be directed at enhancing resilience by improving the ability of cities and communities to resist, absorb, accommodate to and recover from the effects of a natural hazard in a timely and efficient manner, including the preservation and restoration of their essential basic structures and functions (UNISDR, 2011).
\end{abstract}

The resilient system concept and disaster risk management (DRM)

The resilient system concept denotes a set of available resources and capacities that can be deployed in response to disturbances and that involve the development/formulation and implementation of efficient adjustment/adaptation strategies to allow a system to deal with current and future events. Enhancing the resilience of urban systems primarily entails establishing efficient DRM. In general, DRM implies taking action before, during, and after disasters to avoid or mitigate their consequences. Modern DRM concepts promote changes of the nature of decision-making to ensure that benefits of sustainability are recognised, and capacity is developed, for adaptation to climate change (UNISDR 2014). Although the ultimate responsibility for efficient DRM rests with public administration, the concept of resilience is founded upon the capacities of the community itself. This implies integration between the activities of society and those of institutions, together with a robust institutional foundation that can be secured through capacity-building, appropriate governance, promotion of policies and legislation, provision of information, and implementation of efficient co-ordination mechanisms. 
DRM at the local level

Local government is seen as the first line of response, and its capacity is thought to directly affect the degree of disaster protection available. Although appropriate policies and institutional framework are preconditions for successful DRM, the development of resilient communities is increasingly becoming a primary duty of local authorities. Local governments have the institutional and political responsibility for protecting their residents, and are the first level of government to take measures to reduce disaster risk, come up with answers to future risks, and respond to disasters (UNISDR, 2012). Apart from local authorities, all other relevant stakeholders must engage to make cities more resilient: these include national governments, international and regional organisations, local communities, the civil society, professional associations, private and corporate sectors, donors, and academia.

Enhancing disaster risk management at the local level is particularly a problem for developing countries, where economic issues are compounded by the lack of professional capacity in local government, absence of strategic urban development, poor oversight of construction and service delivery, and exclusion of citizens from decision-making.

\section{The DRM model as applied in Obrenovac}

In May 2014, catastrophic floods struck Serbia and the broader region. This disaster caused the greatest damage to Obrenovac, a town within the metropolitan area of Belgrade, the Serbian capital. The floodwaters completely inundated Obrenovac after embankments had given way along two of the three rivers surrounding the settlement. The floods killed 17 people and forced 25,000 local inhabitants to temporarily evacuate their homes. The damage, as well as relief and recovery costs, ran into billions of euros.

In both Obrenovac and other 24 affected communities in Serbia, the May 2014 flooding was the consequence of the interaction between natural and man-made factors. The primary natural cause was extreme precipitation, with 100-year recurrence for many river basins and even 1000 -year recurrence for some. The most significant man-made aspects were the lack of communication between authorities concerning warnings of massive precipitation and forecasts indicating that rising water levels would trigger emergency measures; incomplete flood defence systems along riverbanks; and exceptionally poor maintenance of regulated riverbeds and defensive embankments. Systemic issues mainly involved the lack of investment into anti-erosion works and afforestation; inadequate spatial and urban planning and illicit construction close to urban watercourses; inadequate waste disposal arrangements that reduced stream flow and dramatically increased water pollution; etc. (Milosavljevic, 2014).

The damage caused to the members of the public and the environment revealed the true state of the disaster management sector in Serbia's towns. The experience with the floods drew attention to the need to construct a comprehensive risk management system and embrace the concept of resilience as a key framework for spatial planning and development. Although major advances have been made over the past decade to enhance DRM and incorporate disaster risk reduction into urban and spatial governance in Serbia (legislation, strategic documents, state of play reports), legislation remains insufficiently interlinked and mutually aligned, and governance instruments are still inadequate, as are the human capacities to implement them, especially at the local level. 
Development of a DRM model for Obrenovac

'Disaster Risk Management at the Local Level' was the title of a final project carried out by the students of the Integrated Urbanism master's programme for the academic year 2014/15. Students' master's theses and designs were developed in collaboration with the GIZ-AMBERO project 'Strengthening of Local Land Management in Serbia', and focused on the issue of climate change and its impact on urban development in the context of the catastrophic flooding that affected Serbia in the spring of 2014. The project relied on How to Make Cities More Resilient, a handbook published by the United Nations Office for Disaster Risk Reduction (UNISD, 2012), and the sub-topics highlighted in this document. The urban municipality of Obrenovac, which suffered most damage in the 2014 floods, was chosen as the test site for the designs.

Work on students' assignments was conceptually based on the five-step process identified in the UNISDR report: 1) Organising and preparing to incorporate the 'ten essentials' for resilient cities; 2) Diagnosis and assessment of the city's risk; 3) Developing a safe and resilient city action plan; 4) Implementing the plan; and 5) Monitoring and follow-up. The students' works involved the development of the first three steps.

These 'ten essentials', as defined in the UNISDR handbook, formed the backbone of the students' assignments:

1. institutional and administrative framework;

2. financing and resources;

3. multi-hazard risk assessment;

4. infrastructure protection, upgrading and resilience;

5. protect vital facilities: Education and health;

6. building regulations and land use planning;

7. training, education and public awareness;

8. environmental protection and strengthening of ecosystems;

9. effective preparedness, early warning and response;

10. recovery and rebuilding communities (UNISDR, 2012).

Students' final works represent a collection of integrated urban designs intended to manage flood risk in the territory of the Municipality of Obrenovac, and taken together constitute an outline of Safe and Resilient Action Plan that corresponds to the recommendations of the UNISDR handbook (Fokdal \& Zehner, 2016; Maruna \& Čolić, 2015; Maruna et al., 2015; Čolić et al, 2015).

Keywords: disaster risk management, local authority, urban resilience, integrated urban projects 